\title{
Age frequency distribution and revised stable isotope curves for New Zealand speleothems: palaeoclimatic implications.
}

\author{
Paul W. Williams ${ }^{1}$, Helen L. Neil ${ }^{2}$ and Jian-Xin $Z_{\text {hao }}^{3}$
}

\begin{abstract}
:
Williams P. W., Neil H. and Zhao J-X. 2010. Age frequency distribution and revised stable isotope curves for New Zealand speleothems: palaeoclimatic implications. International Journal of Speleology, 39(2), 99-112. Bologna (Italy). ISSN 0392-6672.

The occurrence of speleothems in New Zealand with reversed magnetism indicates that secondary calcite deposition in caves has occurred for more than 780 thousand years (ka). 394 uranium-series dates on 148 speleothems show that such deposition has taken place somewhere in the country with little interruption for more than $500 \mathrm{ka}$. A relative probability distribution of speleothem ages indicates that most growth occurred in mild, moist interglacial and interstadial intervals, a conclusion reinforced by comparing peaks and troughs in the distribution with time series curves of speleothem $\delta^{18} \mathrm{O}$ and $\delta^{13} \mathrm{C}$ values. The stable isotope time series were constructed using data from 15 speleothems from two different regions of the country. The greater the number of overlapping speleothem series (i.e. the greater the sample depth) for any one region, the more confidence is justified in considering the stacked record to be representative of the region. Revising and extending earlier work, composite records are produced for central-west North Island (CWNI) and north-west South Island (NWSI). Both demonstrate that over the last 15 ka the regions responded similarly to global climatic events, but that the North Island site was also influenced by the waxing and waning of regional subtropical marine influences that penetrated from the north but did not reach the higher latitudes of the South Island. Cooling marking the commencement of the last glacial maximum (LGM) was evident from about $28 \mathrm{ka}$. There was a mid-LGM interstadial at 23-21.7 ka and Termination 1 occurred around $18.1 \mathrm{ka}$. The glacial-interglacial transition was marked by a series of negative excursions in $\delta^{18} \mathrm{O}$ that coincide with dated recessional moraines in South Island glaciers. A late glacial cooling event, the NZ Late Glacial Reversal, occurred from 13.4-11.2 ka and this was followed by an early Holocene optimum at 10.8 ka. Comparison of $\delta^{18} \mathrm{O}$ records from NWSI and EPICA DML ice-core shows climatic events in New Zealand to lag those in Antarctica by several centuries to a thousand years. Waxing and waning of subantarctic and subtropical oceanic influences in the Tasman Sea are considered the immediate drivers of palaeoclimatic change.
\end{abstract}

Keywords: speleothems, New Zealand, palaeoclimate, stable isotopes, uranium series

Received 4 April 2010; Revised 10 May 2010; Accepted 7 June 2010

\section{INTRODUCTION}

The purpose of this paper is threefold: to present the record of uranium-series ages obtained from New Zealand speleothems; to revise and extend previously published stable isotope records; and to assess the palaeoclimatic significance of these data.

The palaeoclimate significance of growth frequency variations of secondary calcite deposits in caves in Europe has been examined by Gordon et al. (1989), Lauritzen (1993), Baker et al. (1993), and Hercmann (2000), the collected results being reviewed by Richards and Dorale (2003). It was concluded that in these mid-latitude regions speleothem growth was slowed significantly during cool glacial periods, if not stopped, and also that growth was limited in

1 School of Environment, University of Auckland, PB 92019, Auckland 1142, New Zealand. E-mail: p.williams@auckland.ac.nz 2 National Institute of Water and Atmospheric Research, Kilbirnie, PB 14901, Wellington, New Zealand

3 Radiogenic Isotope Laboratory, Centre for Microscopy and Microanalysis, University of Queensland, Brisbane, Queensland 4072, Australia. times of relative aridity. Independent changes in either temperature or aridity or both can determine periods of enhanced or reduced speleothem growth. Particularly high levels of growth frequency were identified in the Holocene and Last Interglacial, when conditions in Europe were both warm and wet; and a lesser but still significant increase in growth was also observed during interstadial marine isotope stage (MIS) 3. Although speleothem growth ceased in Europe under glaciated areas, it continued - albeit at a slower rate- in areas that were not being glaciated.

The importance of aridity in reducing speleothem growth is especially evident in Australia. Ayliffe et al. (1998) examined 49 age estimates of speleothems from South Australia, an unglaciated region, and identified four main growth periods: 20-115 ka, $155-220 \mathrm{ka}, 270-300 \mathrm{ka}$ and $340-420 \mathrm{ka} \mathrm{BP}$, all of which correspond to cool periods (including stadials and relatively cool interstadials). Unlike in Europe, speleothem deposition in South Australia was not observed during interglacials and warm interstadials, but occurred in stadials right up to glacial maxima when increasingly cool-arid conditions terminated growth. Speleothem growth appeared to coincide 
with known pluvial episodes when high lake levels were recorded in the region (Ayliffe et al. 1998). Water balance conditions are clearly critical and, like a tap, can turn speleothem growth on or off. Cool periods are conducive to speleothem growth in South Australia because water losses by evapotranspiration are minimized and there is a water surplus. When it is warm there is a water deficit.

New Zealand's climate is oceanic and more like Western Europe than South Australia. New Zealand is located in the mid-latitudes of the south-west Pacific and extends across $13^{\circ}$ of latitude between $34^{\circ}$ and $47^{\circ} \mathrm{S}$ (Fig. 1). Its land area is $265150 \mathrm{~km}^{2}$. The southern edge of the subtropical gyre in the Tasman Sea between New Zealand and Australia introduces warm waters to the North Island, whereas offshoots of the Antarctic circumpolar circulation surround the South Island with cool subantarctic waters (Fig. 2). New Zealand is therefore midway between tropical and Antarctic influences - tropical cyclones sometimes intrude from the north and icebergs occasionally drift in from the south. Sea surface temperatures range from an average of $21^{\circ} \mathrm{C}$ in the north to $8{ }^{\circ} \mathrm{C}$ in the south and oceanic source waters for precipitation are of subtropical origin in the north and of subantarctic origin in the south. The country is situated transverse to the circum-polar westerly wind circulation, so windward localities are wet and there is a marked rain-shadow effect in the east. Temperate evergreen rainforests cover western slopes.

During the Pleistocene the country experienced extensive mountain valley glaciation in the Southern Alps and on the highest peaks of the North Island. However, even during the height of glaciations most of the country remained ice-free (Shulmeister and McGlone 2008) and relatively mild, because of surrounding maritime influences. Forest cover during glacial episodes was limited to the northern third of the North Island and, except for the highest glaciated peaks, the remainder of the island was covered with shrubland and grassland, which also extended around most coastal lowlands of the South Island. When sea level was at $-80 \mathrm{~m}$ or below, the two islands were connected by a land bridge.

\section{DISTRIBUTION OF SPELEOTHEM AGES}

Although carbonate rock outcrops cover only about $3 \%$ of New Zealand, these rocks are widely distributed through the country, and caves with speleothems are found in most regions (Crossley 2001, Crossley et al. 1988, Smith 2004) . Many caves in New Zealand are relatively young, because uplift and karstification is geologically recent. Most uplift began between $8 \mathrm{Ma}$ and $3 \mathrm{Ma}$, depending on the location in the country (Williams 2004a), and karstification occurred mainly in the Quaternary (Williams 1992). In the Waitomo area of the central-west North Island (CWNI), for example, polygonal karst is developed in Oligocene limestones, but uplift and exposure only commenced in the Pliocene and speleogenesis started mainly in the Pleistocene. Hence the upper levels of the longest cave in the region (Gardners Gut, $12.2 \mathrm{~km}$ ) has speleothems dating from the Last Interglacial (Williams 2004b) and it is likely that the initiation of most caves has taken place within the last half million years and often much more recently. Older caves are known from the South Island, the oldest dated deposit in a cave being marine gravels that were injected into Wet Neck Cave, a karst cave, in coastal north-west South Island (NWSI) during a high sea level stand. A cosmogenic burial age date on marine quartz gravels in the cave indicates their emplacement $1.25 \pm 0.43$ million years ago (D. Fabel pers. com., in Williams 2004c). In spite of the large error term, this shows that the cave existed in the mid-Pleistocene prior to its invasion by the sea (Williams 1982). It is possible that still older caves occur in NWSI, especially in the marble mountains of Mt Arthur and Mt Owen, where there are caves to $66 \mathrm{~km}$ in length and over $1 \mathrm{~km}$ depth.

New Zealand caves are abundantly decorated with speleothems. This reflects the moderate maritime climate that affects the country; it is generally mild and moist with few temperature extremes, although in the high mountains there are permanent glaciers. The oceanic influence is also evident in the relationship of speleothem $\delta^{18} \mathrm{O}$ to temperature, which is generally positive (Williams et al. 2004, 2005, Whittaker 2008), although there are exceptions, for example Hellstrom et al. (1998) found there to be a negative $\delta^{18} \mathrm{O}$ relationship to temperature at an alpine site. But this is unusual, the relationship is normally dominated by the precipitation effect, characterised by a positive relationship between $\delta^{18} \mathrm{O}$ of precipitation and temperature (Dansgaard 1964, Bowen and Wilkinson 2002, Kohn and Welker 2005). Thus, for example, between Kaitaia in the north of New Zealand, which is an IAEA/WMO Isotopes-Precipitation Network site, and Invercargill in the south (Fig. 1) there is a mean annual temperature difference of $6.2^{\circ} \mathrm{C}$ and a positive relationship between $\delta^{18} \mathrm{O}$ of precipitation and temperature of $+0.35 \%$ o $/{ }^{\circ} \mathrm{C}$. This value exceeds the negative cave temperature effect $\left(-0.24 \%\right.$ o $\left.{ }^{\circ} \mathrm{C}\right)$, which is associated with the thermodynamic fractionation between calcite and water as speleothem calcite is deposited (Ford and Williams 2007), and so the resultant is positive.

\section{Speleothem sample sites and uranium-series ages}

The distribution of carbonate rocks in New Zealand (Fig. 1) determines cave locations from which speleothem samples can be obtained. Some regions are of particular importance because of their well developed karst in crystalline Oligocene limestones or Ordovician marble (Williams 1992). Consequently most samples have been obtained from the north-west of the South Island (NWSI) and central-west North Island (CWNI); regions known locally as north Westland-NW Nelson and the King Country, respectively. Although limestones are well distributed along the eastern side of the country, they tend to be young or poorly cemented (for example, upper Pliocene coquinas), so caves and sampling opportunities are relatively limited, though these young porous limestones still contain caves. 


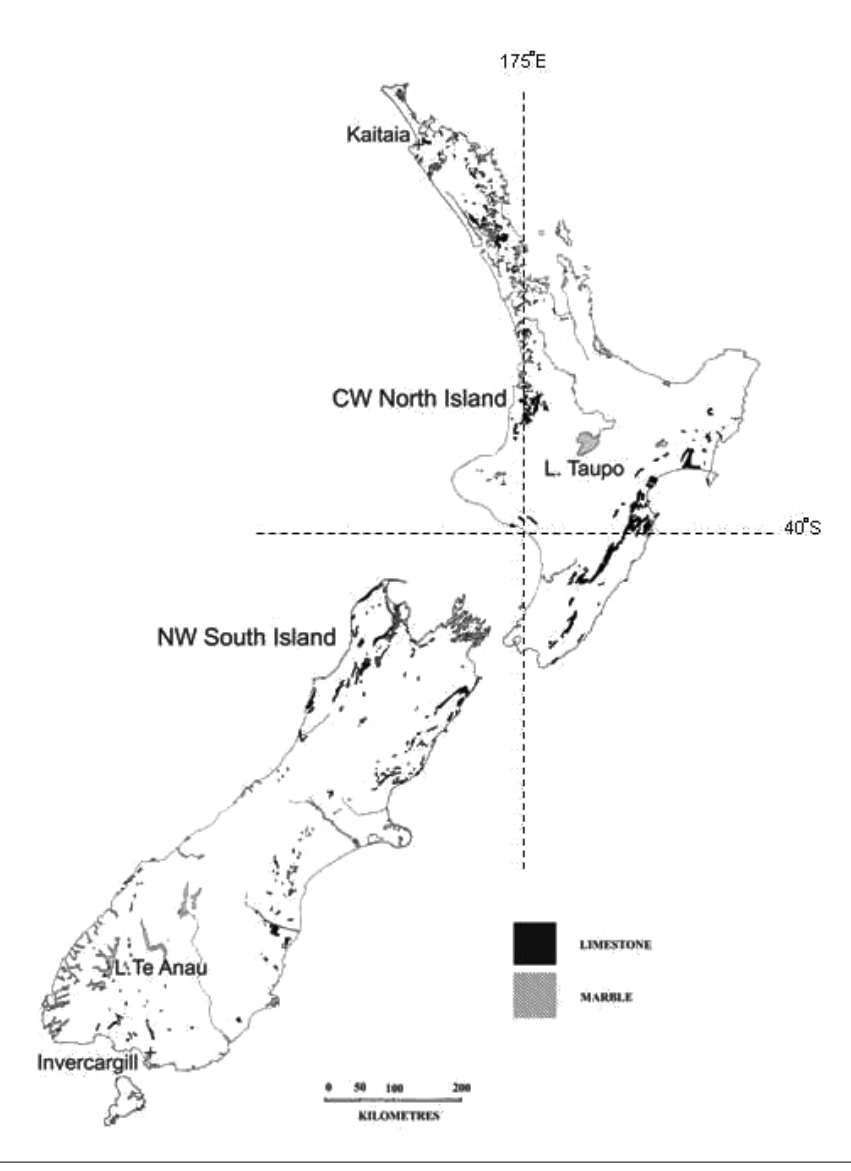

Fig. 1. The distribution of limestone and marble karst in New Zealand. Most speleothem samples have been obtained from central-western North Island (CW NI) and north-west South Island (NW SI).
A data set of 394 uranium-series ages has been compiled from a total of 148 speleothems obtained throughout the country. Published sources of ages include Crawford (1994), Hellstrom et al. (1998), Lorrey et al. (2008), Whittaker (2008), Williams (1982, 1996), and Williams et al. (2004, 2005). Most of the ages (287) were determined by TIMS and the remainder by a-counting.

\section{Speleothem age-frequency distribution}

A relative probability frequency distribution curve of speleothem ages (Fig. 3) was constructed using Isoplot 3.6 from Ludwig (2008), the input data set comprising 394 uranium-series ages with associated $2 \sigma$ error terms. The distribution of ages reflects periods when environmental conditions in some parts of the country (not necessarily everywhere) were suitable for speleothem growth. However, two points are important when interpreting the graph: (1) although troughs in the distribution probably indicate that conditions were relatively unfavourable for speleothem growth, they may also reflect insufficient sampling, because New Zealand caves have abundant deposits of secondary calcite and only small areas of karst were directly affected by glaciation and nowhere by permafrost. (2) A sampling strategy that has focused on the Holocene and the last glacial cycle partly explains the abundance of relatively young samples and lower representation of speleothems aged $>150$ ka, especially because some of the relatively young

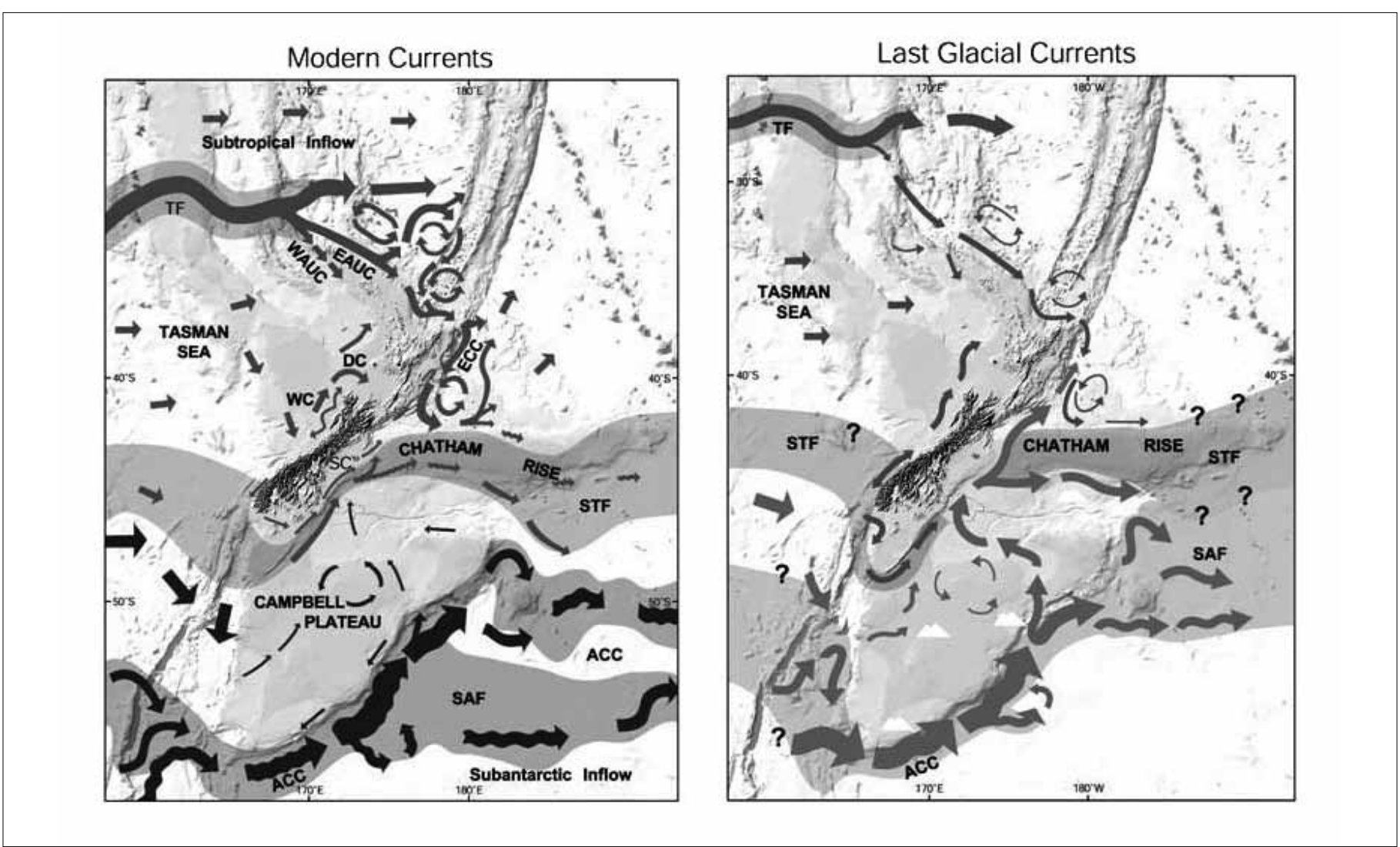

Fig. 2. Modern and Last Glacial Maximum ocean circulation around New Zealand. The country is located between a subtropical circulation in the north and subantarctic circulation in the south. Variations in the relative strength of these currents and the position of the tropical and subtropical fronts influences the source water $\delta 180$ values of precipitation over New Zealand. TF Tropical Front, STF Subtropical Front, SAF Subantarctic Front, WAUC West Auckland Current, EAUC East Auckland Current, WC Westland Current, DC Durville Current, ECC East Coast Current. (From Carter in Neil et al., 2004). 


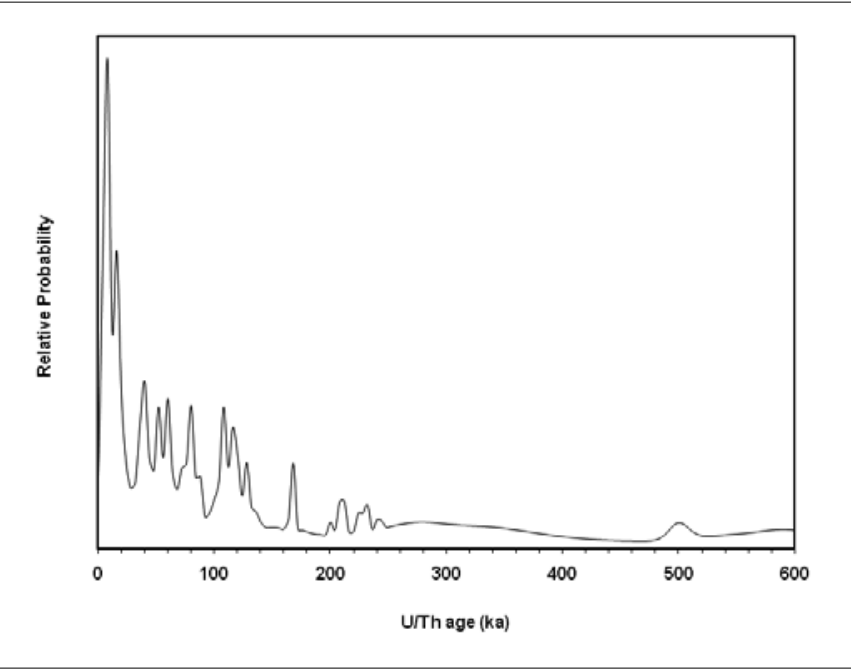

Fig. 3. Relative probability plot of New Zealand speleothem uraniumseries ages. The distribution is influenced by a research strategy that has emphasized sampling and dating at the younger end of the spectrum. The probability plot was constructed using Isoplot (Ludwig 2008).

speleothems have high densities of dates, whereas older samples tend to have fewer dates. Consequently, not too much should be read into the relative heights of peaks or into long intervals with low frequencies of dates at the older end of the curve. Nevertheless, despite these caveats regarding interpretation, interesting peaks and troughs occur in the relatively probability distribution.

There is a preponderance of dates in the last 15 $\mathrm{ka}$, as is the case in Europe (e.g Baker et al. 1993), because conditions in the present interglacial have been mild and humid, thus favouring speleothem growth. During the global Last Glacial Maximum (LGM), between about $18-28$ ka in New Zealand (Alloway et al. 2007), there was relatively little speleothem deposition, probably because conditions at the time were cool and relatively dry (Shulmeister and McGlone 2008). MIS 3 was a mild interstadial, and spectral peaks occur at $43 \mathrm{ka}, 52 \mathrm{ka}$ and $61 \mathrm{ka}$ at the MIS 3/4 transition. New Zealand experienced the largest advance of the last glacial cycle around $70 \mathrm{ka}$ and at that time speleothem deposition diminished, probably because conditions were relatively cold and dry. In MIS 5 peaks can be observed at $79 \mathrm{ka}$ (MIS 5a), $108 \mathrm{ka}$ (MIS 5c), $117 \mathrm{ka}$ and $128 \mathrm{ka}$ (MIS 5e); and they occurred in interstadial and interglacial intervals when the climate would have been relatively warm and humid. Beyond the Last Interglacial at the older end of the spectrum, peaks are less obvious due to a small number of relatively evenly distributed ages coupled with comparatively large age errors. Only 28 ages ( $7 \%$ of the data set) are from speleothems older than $150 \mathrm{ka}$. Thus although there are small peaks at 169 ka (MIS 6), $208 \mathrm{ka}$ and $232 \mathrm{ka}$ (MIS 7) and $496 \mathrm{ka}$ (MIS 13), their palaeoclimatic significance must be considered uncertain.

The significance of peaks and troughs in the younger part of the relative probability distribution can be explored further by comparing the distribution to stable isotope records.

\section{STABLE ISOTOPE RECORDS}

\section{Composite stable isotope series}

The composite $\delta^{18} \mathrm{O}$ records previously published in Williams et al. $(2004,2005)$ are up-dated in Figs 4 and 5 , respectively, and the corresponding speleothem $\delta^{13} \mathrm{C}$ records in Fig. 6 . The new data that contribute to these records are provided in the Appendix. The lower parts of the figures show the number of speleothems and their age spans that were combined to construct each composite record.

Composite series were assembled by adjustment of means following the procedure explained in Williams et al. $(2004,2005)$. The common mean selected was that of the speleothem with the longest record. The next longest record was then selected and its mean $\delta$-value was adjusted to that of the reference series, and the process was repeated for the remaining speleothems. The individual means-adjusted records were then combined chronologically into one composite series and this was then filtered using a five-point running mean. The value of combining individual records in this way is that general trends are accentuated while local and random effects are suppressed.

Composite series are preferred to individual records when interpreting palaeoclimatic events, because in New Zealand individual records display sufficient differences in detail to make it difficult to select any one record objectively as being representative of the region from which it came. This raises a significant issue, because an important consideration in science is the extent to which any given conclusion can be reproduced and thus confirmed. This problem is especially evident when dealing with proxy palaeoclimate records, because they may be difficult to obtain and hard to duplicate, and the problem is often overlooked when dealing with speleothem records, partly because conservation issues place justifiable constraints on replicate sampling. Nevertheless, the issue of the representativeness of individual speleothem samples remains and was illustrated in earlier work (Williams et al. 2004, 2005). The revised records presented here improve the reliability of the series, because in the case of CWNI seven stable isotope records have been superimposed rather than four, as was the case previously, and in the case of NWSI there are 13 more dates and 68 extra stable isotope data points.

It is possible that replication of records may be easier in climatic regions where there are strong seasonal differences, such as monsoon areas of China for example (Yuan et al. 2004), but even there reproducibility of records should be demonstrated rather than assumed before they are taken as being representative.

In addition to the issue of record reproducibility, construction of composite series is also required to obtain long proxy records in places where most speleothems have only grown for relatively short periods. New Zealand is a tectonically young and active country with generally young and dynamic caves. Many speleothems sampled grew for the order of 10 

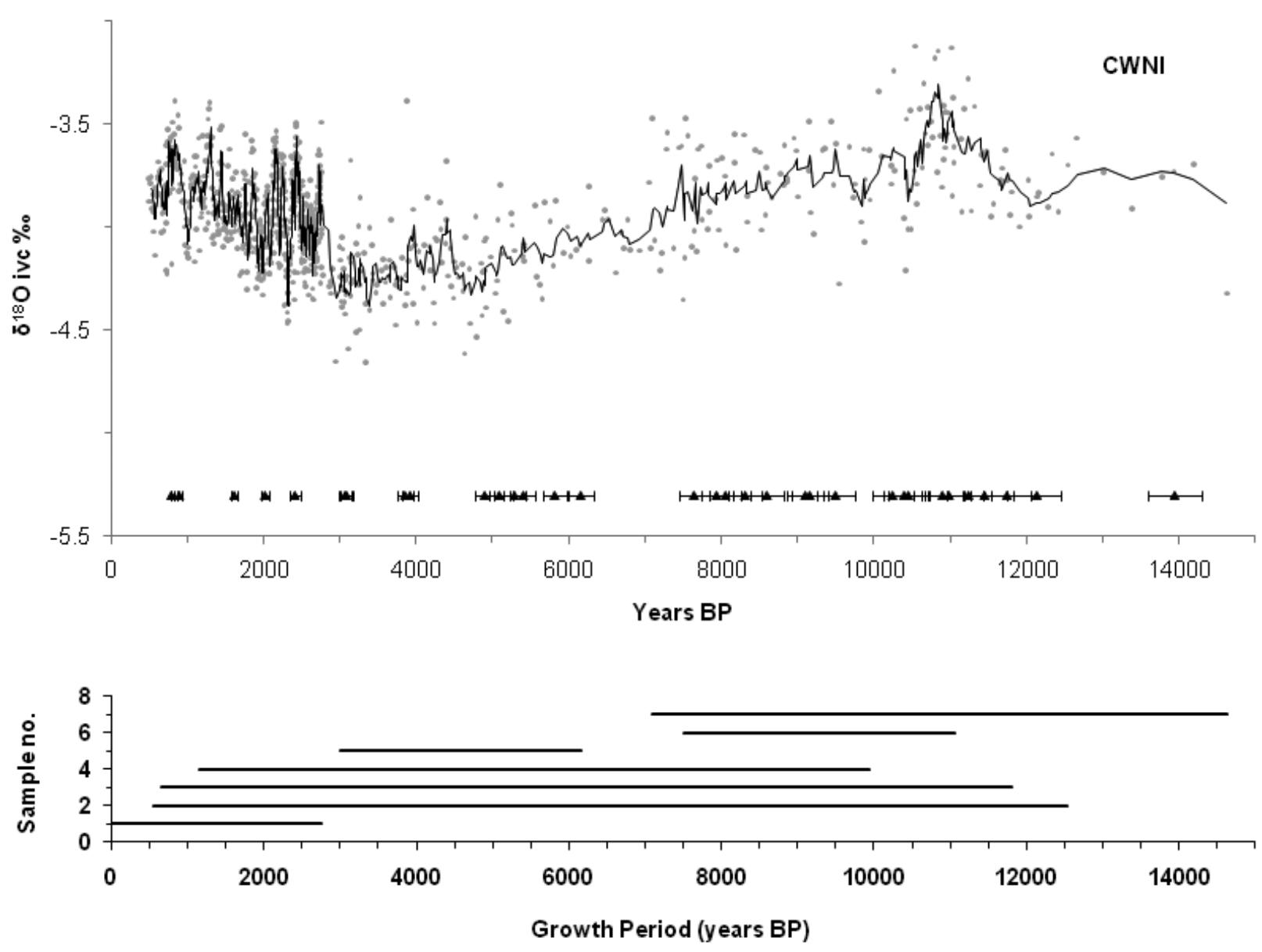

Fig. 4. Upper. Up-dated composite curves of speleothem $\delta^{18} \mathrm{O}$, ice volume corrected (ivc), for the Waitomo district of central-west North Island. The original curve published by Williams et al. (2004) was based on 4 speleothems with 19 TIMS dates. It extended to 11814 years BP and was assembled from 301 stable isotope data points. The new record is constructed from 7 speleothems with 34 dates and 934 stable isotope data points, and extends from 500 - 14625 years BP. All series are in isotopic equilibrium. TIMS dates with $2 \sigma$ error bars are shown, although sometimes the bars lie within the symbol. Details of the 3 new records are provided in Appendix, Figs A1 to A4.

Lower. The number of overlapping speleothems (sample depth) is greatest from 3-6 ka and 7.5-10 ka, but the record relies on only one speleothem beyond $12.5 \mathrm{ka}$.

thousand years or so, and only a few accumulated in conditions that have permitted growth for more than 50 thousand years.

The confidence that can be placed in composite records varies along their length. This is well known in dendrochronology where master series are constructed from numerous individual records and where the number of samples that have contributed to the composite record is referred to as sample 'depth'. From Figs 4 and 5 it can be seen that the composite series in some time intervals relies on only one speleothem, but in other places is the average of five records. Individual speleothems with higher than average sampling frequency may also dominate other records. Thus the reliability of composite records as representative of a region increases with sample depth, but may also vary along the length of a series as the number of stable isotope data points contributing to the record changes.

Comparison of the relative probability distribution in Fig. 3 with the stable isotope curves in Figs 4 and 5 sheds some light on the relationship between speleothem growth and climate. It is evident that the major trough in the distribution around 30-20 ka broadly corresponds with cool dry conditions of the Last Glacial Maximum (LGM) and that the peak after 15 ka coincides with postglacial climatic amelioration. This reinforces our present understanding of the climatic factors influencing speleothem growth (Ford and Williams 2007). One may also observe that in the warm early Holocene the peak in relative probability was associated with comparatively positive $\delta^{18} \mathrm{O}$ values and that the LGM trough was associated with comparatively negative values. This reflects the positive relationship of speleothem $\delta^{18} \mathrm{O}$ to temperature previously noted by Williams et al. $(2004,2005)$ and Whittaker (2008).

\section{Regional effects}

If the CWNI and NWSI $\delta^{18} \mathrm{O}$ records are compared (Fig. 7), it is clear that both have key features in common, but there are also some marked differences. For example, in both records one may identify the trough in values representing the NZ Late Glacial Reversal at 13.4-11.2 $\mathrm{ka}$ and the peak during the early Holocene warm event at $10.8 \mathrm{ka}$ (both discussed in Alloway et al., 2007). But whereas the NWSI record varies about an almost stationary trend through the 

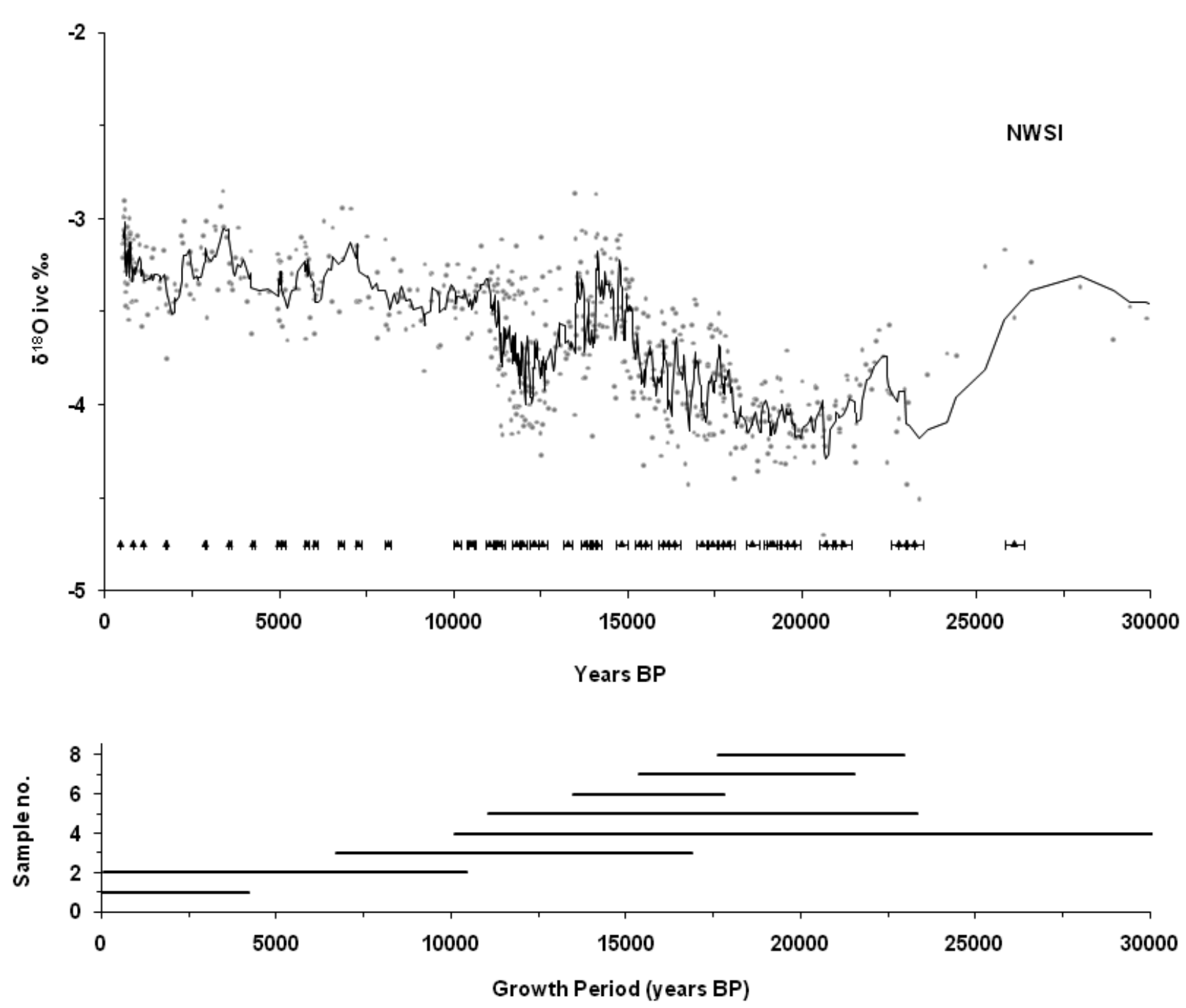

Fig. 5. Upper. Up-dated composite curves of speleothem $\delta^{18} \mathrm{O}$, ice volume corrected (ivc), for coastal regions of north-west South Island. The original curve published by Williams et al. (2005) was based on 8 speleothems with 43 TIMS dates. It extended to 23355 years BP and was assembled from 573 stable isotope data points. The new record is constructed from the same 8 speleothems but has 56 dates and 641 stable isotope data points, and extends from 500 - 30000 years BP. TIMS dates with $2 \sigma$ error bars are shown, although sometimes the bars lie within the symbol. All series are in isotopic equilibrium.

Lower. Sample depth varies along the record, being greatest between from 10-17 ka and least from 4.2-6.7 ka and after $23.3 \mathrm{ka}$.

mid-Holocene, the CWNI record shows a distinct downward slope towards $3 \mathrm{ka}$ BP. An explanation is clearly required for the occurrence of a cooling trend in the western North Island but not in the northwestern South Island.

Because of the oceanic nature of New Zealand's climate, the explanation is likely to reside in the waning of subtropical influences in the northern Tasman Sea. This could come about as a result of the weakening of the subtropical gyre in the Tasman Sea and in the correspondingly reduced southerly penetration of the warm West Auckland Current (WAUC, Fig. 2). This interpretation is supported by evidence for a general decline of about $2.5^{\circ} \mathrm{C}$ in sea surface temperatures after $11 \mathrm{ka} \mathrm{BP}$, as estimated by Barrows et al. (2007) using the alkenone-unsaturation technique. The north-west South Island was not noticeably impacted by this presumably because the cool northwards flowing Westland and Durville Currents (WC, DC, Fig. 2) maintained or extended their influence as the West Auckland Current waned.

The above example illustrates the contrasts that can occur in regional records, yet New Zealand is a small country by international standards and so at a global scale might be taken as one region, in spite strong internal climatic variations. So if regional records are combined in order to generate a national record, then the underlying regional contrasts are expressed as a wide scatter of data points. This is illustrated by the effect of combining CWNI and NWSI records for the last $15 \mathrm{ka}$ (Fig. 8). It is evident from this that much of the variability along the resulting record is a statistical artefact of data merger rather than a reflection of real climatic variability. Hence studies of climate variability should use individual records only.

\section{Palaeoclimatic interpretation}

The up-dated speleothem $\delta^{18} \mathrm{O}$ records reinforce palaeoclimatic interpretations made previously (Williams et al. 2004, 2005), but permit refinement 

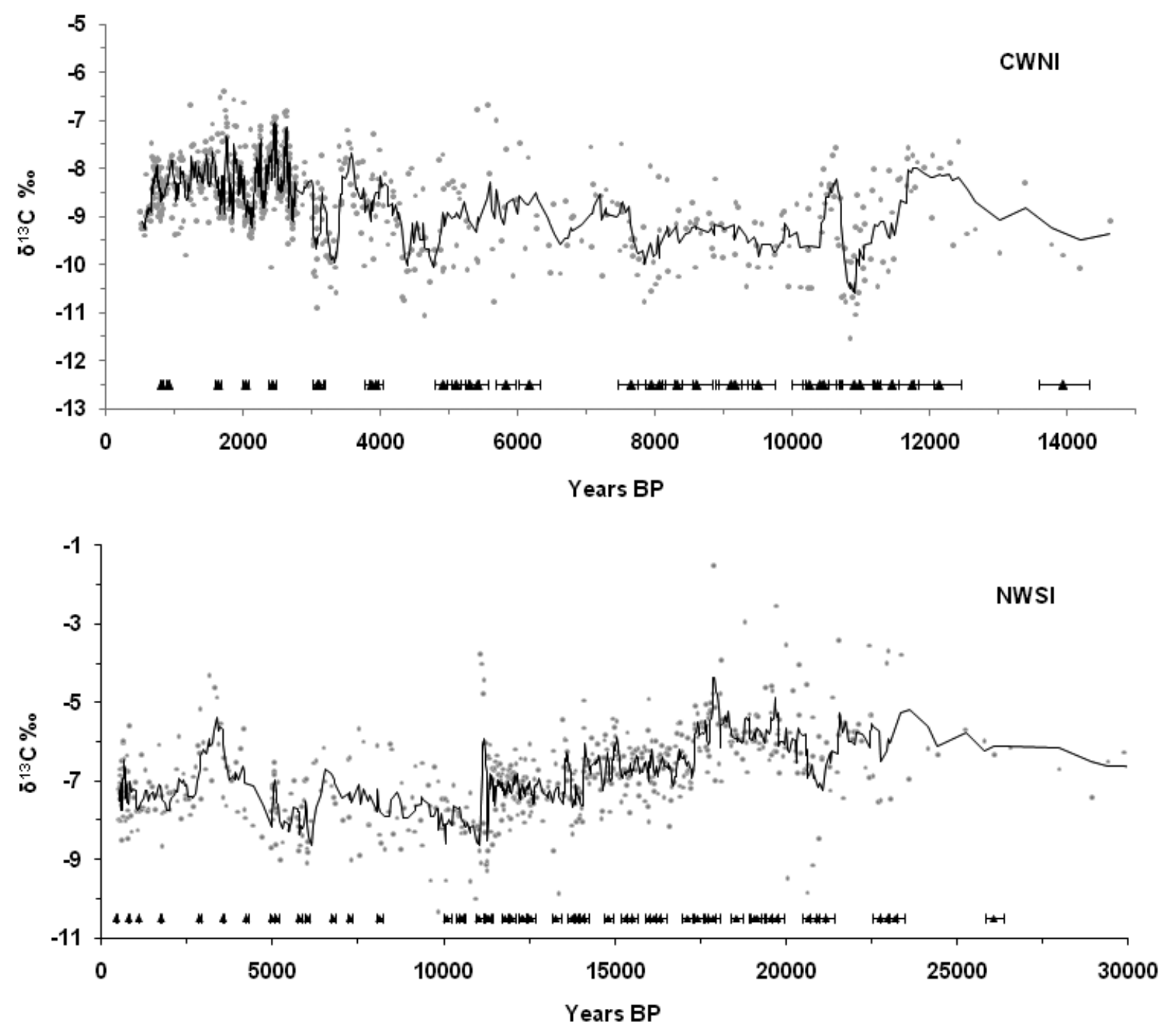

Fig. 6. Up-dated composite curves of speleothem $\delta^{13} \mathrm{C}$ for (Upper) central-west North Island and (Lower) north-west South Island.

of the timing of palaeoclimatic events. Fig. 9 shows the 5-point running mean of the NWSI speleothem $\delta^{18} \mathrm{O}$ record plotted against the Antarctic $\delta^{18} \mathrm{O}$ record from EPICA Dronning Maud Land (EDML) ice-core (EPICA Community Members 2006). Although the icecore data end at $10 \mathrm{ka}$, this series is preferred to the longer EPICA $\delta$ D record (Jouzel et al. 2007) because its higher resolution through the LGM permits closer comparison of events. In both cases $\delta^{18} \mathrm{O}$ has a positive relationship to temperature. Major Antarctic Isotope Maxima (AIM) are indicated on the EDML curve.

The mid-latitude NWSI and the Antarctic EDML records have broad features in common, notably a clear passage into and through the LGM and a Late Glacial reversal. An Antarctic interstadial (AIM4) occurs around $28.8 \mathrm{ka}$ after which the EDML record shows decreasing $\delta^{18} \mathrm{O}$ values until $27.5 \mathrm{ka}$. This marks the commencement of the LGM. The low resolution of stable isotope data points and dates in the earliest part of the NWSI record results in the corresponding decrease in speleothem $\delta^{18} \mathrm{O}$ values being only discernable from $26.1 \mathrm{ka}$. However, significant early LGM glaciation in the Southern Alps is indicated by cosmogenic exposure ages of 27.1 0.9 ka on the highest LGM lateral moraine of the Te Anau

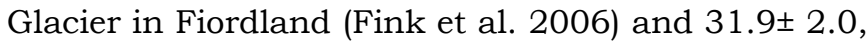
$31.2 \pm 1.3$ and $29.5 \pm 1.8 \mathrm{ka}$ on lateral moraines in south Westland (Sutherland et al. 2007).

The mid-LGM interstadial AIM2 (Fig. 9) commences at $24.4 \mathrm{ka}$, culminates at $23.4 \mathrm{ka}$ and ends by 22.7 $\mathrm{ka}$; a duration of $1.7 \mathrm{ka}$. In the NWSI record this interstadial culminates at $22.1 \mathrm{ka}$ and is $1.2 \mathrm{ka}$ long; thus it lags the Antarctic event by more than $1 \mathrm{ka}$ and is shorter. Conditions remained cool in NWSI for about $3.2 \mathrm{ka}$ from $21.5 \mathrm{ka}$ until the first signs of climatic amelioration between 18.4 and $18 \mathrm{ka}$. In the EDML record gradual warming occurred from $19 \mathrm{ka}$, but there was a sharp increase in $\delta^{18} \mathrm{O}$ values from $18.2 \mathrm{ka}$. The end of the LGM, Termination 1 , therefore occupies a narrow time zone of a few centuries, but in New Zealand may have slightly lagged events in Antarctica. It is most clearly defined in the NWSI $\delta^{13} \mathrm{C}$ record at $18.1 \mathrm{ka}$ (Fig. 6).

The form of the Last Glacial-Interglacial transition is similar in both curves (Fig. 9), although events in the NWSI record generally lag those in EDML by up to 700 - 900 years. EDML shows increasing 8 -values until $14.9 \mathrm{ka}$ (AIM1) compared to $14.1 \mathrm{ka}$ in NWSI. 


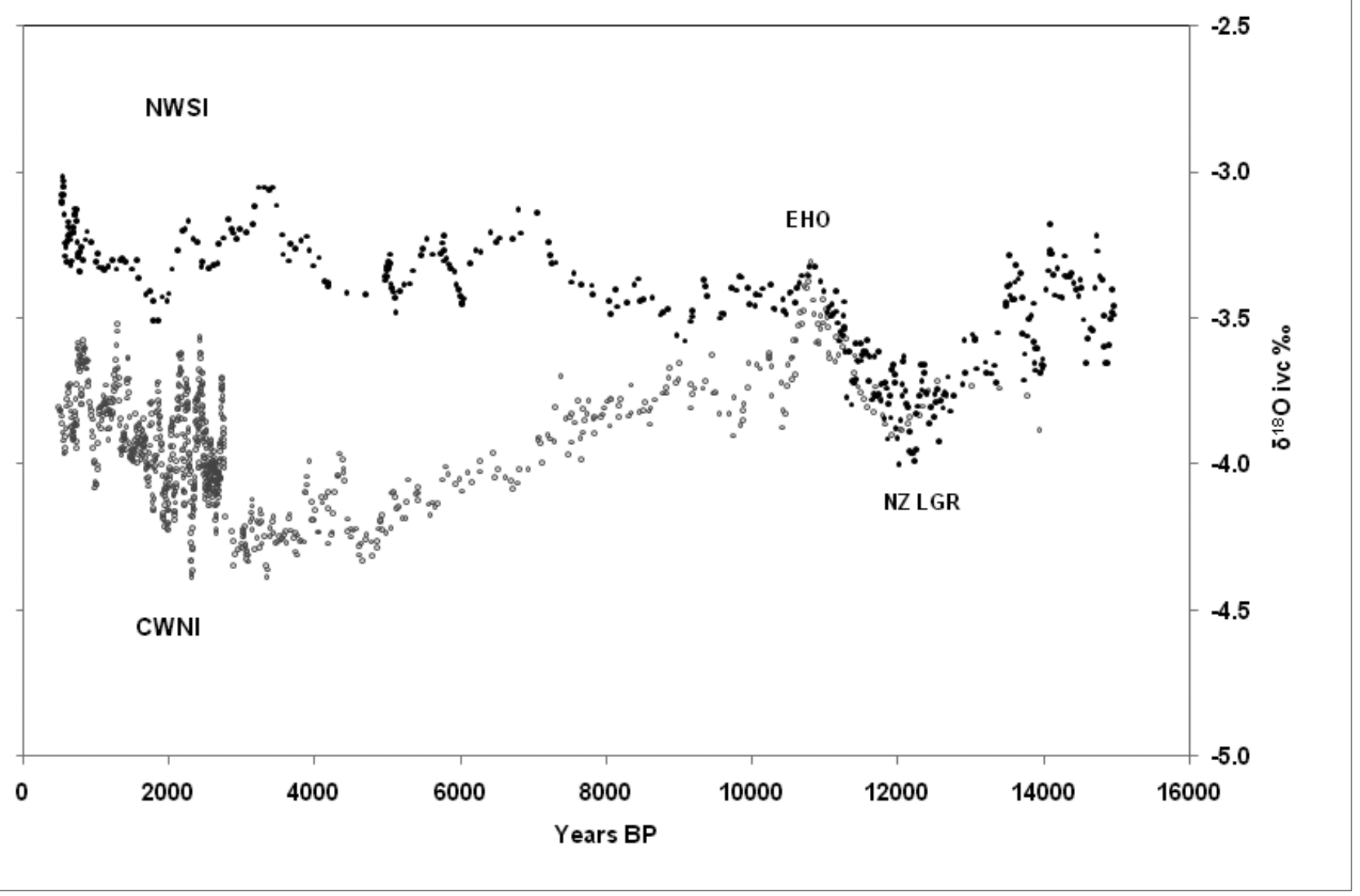

Fig. 7. A comparison of speleothem $\delta^{18} \mathrm{O}$ trends, ice volume corrected (ivc), for the central-west North Island (CWNI) and north-west South Island (NWSI) over the last $15 \mathrm{ka}$. The two curves overlap at the New Zealand Late Glacial Reversal (NZ LGR), but show increasing divergence from the early Holocene optimum $(\mathrm{EHO})$ until around $3 \mathrm{ka}$. The increasingly negative $\delta^{18} \mathrm{O}$ values in $\mathrm{CWNI}$ from $10.5-3 \mathrm{ka}$ are probably attributable to the waning strength of the subtropical gyre and associated reduction in polewards penetration of subtropical source waters in the Tasman Sea; this influence being carried to caves by westerly wind-borne precipitation.

This warm event approximately coincides with the Bølling/Allerød interstadial of Europe. However, both curves indicate the transition to be oscillatory. The saw-tooth pattern is marked in the NWSI case by a series of negative excursions (cooling episodes) at $17.2,16.7,16.2,15.7,15.3,14.8$ and $14.6 \mathrm{ka}$. In the Southern Alps, these excursions were associated with still-stands or minor advances during the general retreat of the alpine glaciers and with the development of recessional terminal and lateral moraines. This association is confirmed by cosmogenic ages of $17.3 \pm$ $0.8,16.6 \pm 0.8,16.3 \pm 0.7,15.7 \pm 0.5$ and $14.2 \pm 2.1$ $\mathrm{ka}$ on recessional moraines in northwest South Island (Shulmeister et al. 2005), as well as by $17.2 \pm 0.7$ and $15.8 \pm 0.8 \mathrm{ka}$ on two of the lateral moraines of the Te Anau Glacier (Fig. 1) in Fiordland (Fink et al. 2006).

A marked cool reversal then followed AIM1, known in Antarctica as the Antarctic Cold Reversal (ACR) and in New Zealand as the NZ Late Glacial Reversal (NZLGR) (Williams et al. 2005). The timing of the cold culmination shows some variability in Antarctica with14.4 $\mathrm{ka}$ in EDML $\delta^{18} \mathrm{O}$ compared to12.5-12.8 $\mathrm{ka}$ in EPICA $\delta \mathrm{D}$, but was at 12-12.2 $\mathrm{ka}$ in NWSI. Nevertheless, in the EDML record the reversal lies between 14.7-12.5 ka compared to $13.4-11.2 \mathrm{ka}$ in NWSI, indicating that the cool event in New Zealand lagged Antarctica by 1000 years or so. As noted previously (Williams et al. 2005), the Younger Dryas chronozone $(\sim 12.9-11.6 \mathrm{ka})$ is entirely contained within the NZLGR interval.

In the EDML record, the Late-Glacial transition gave way to warm Holocene conditions at $11.7 \mathrm{ka}$, although the EPICA $\delta D$ curve (Jouzel et al. 2007) shows a well marked early Holocene climatic optimum from 11.6-9.7 ka. The NWSI curve has an early Holocene culmination at about the same time $(10.8 \mathrm{ka})$ as EPICA, but the warm interval is less pronounced; in fact the positive excursion at $14.1 \mathrm{ka}$ was more marked. From the early Holocene the NWSI curve displays a gentling rising (less negative) but rolling overall trend, whereas the EPICA curve is almost horizontal and displays little variation. Weaver et al. (1998) identified a clear climatic optimum in the marine record off eastern New Zealand between 8 and $6.4 \mathrm{ka}$, and this broadly corresponds to a culmination around $6.9 \mathrm{ka}$ in the NWSI curve.

The NWSI $\delta^{18} \mathrm{O}$ data reveal shallow negative excursions at $9.1,6,5.1,2.5$ and $1.8 \mathrm{ka}$, while the corresponding CWNI curve (Fig. 4) has a significant negative excursion at 3.4-2.9 ka. As remarked when discussing Fig. 7, these oscillations may be associated with the waxing and waning of subtropical marine influences in the Tasman Sea, the effects of which are transmitted inland by precipitation carried by the 

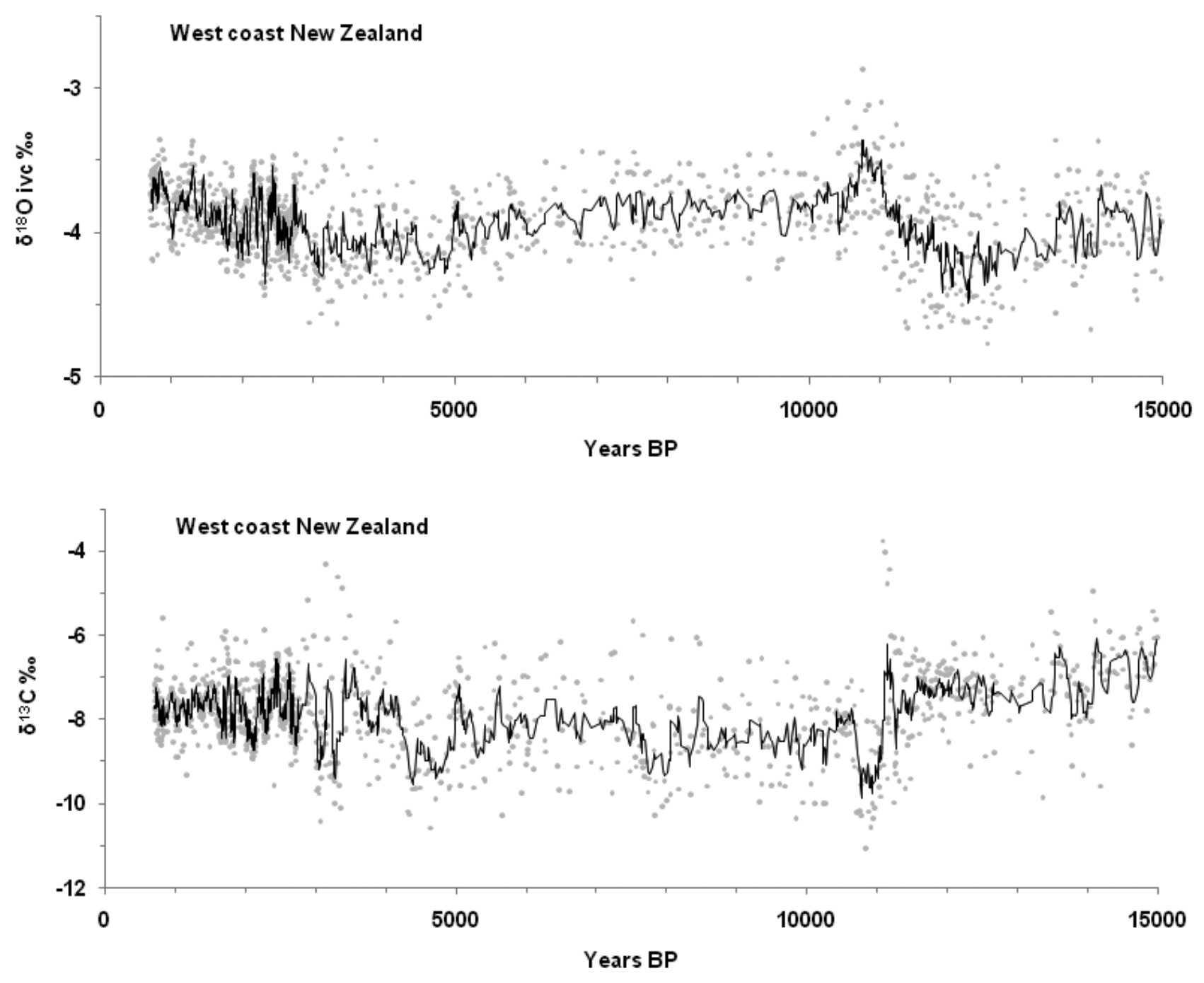

Fig. 8. Composite speleothem $\delta^{18} \mathrm{O}$ and $\delta^{13} \mathrm{C}$ records generalised for west coast New Zealand by merger of CWNI and NWSI data. The upper $\delta^{18} \mathrm{O}$ curve clearly shows the NZ Late Glacial Reversal (13.4 - $11.2 \mathrm{ka}$ ), the early Holocene optimum (10.7 - $11 \mathrm{ka})$, and the neoglacial ( $3 \mathrm{ka}$ ). The lower $\delta^{13} \mathrm{C}$ record shows sharply decreased values during the early Holocene optimum, suggesting relatively wet conditions at that time.

prevailing westerly winds. Some of the cosmogenically dated Holocene glacial advances of the Mueller and Tasman Glaciers in the eastern Southern Alps (Schaefer et al. 2009), notably those at 3.2, 2, 1.84, 1.65 and $1.37 \mathrm{ka}$, coincide with negative excursions in the NWSI and CWNI curves.

The $\delta^{13} \mathrm{C}$ profile (Fig. 6) reveals a series of abrupt changes that reflect environmental conditions affecting biological activity, notably water balance and temperature, as discussed in Williams et al. (2005). In the NWSI record, $\delta^{13} \mathrm{C}$ values are most positive at $18.1 \mathrm{ka}$ (Termination 1) and thereafter rapidly become more negative through the glacialinterglacial transition as climatic amelioration stimulates plant growth. From 13.9-11.1 ka this trend reverses slightly through the NZLGR, but $\delta^{13} \mathrm{C}$ values then suddenly become more negative once climatic conditions attain the early Holocene optimum. This is particularly marked in the CWNI record. It is notable that $\delta^{13} \mathrm{C}$ peaks around $3.4 \mathrm{ka}$ in both NWSI and CWNI coincide with dated glacial advances in the eastern Southern Alps (Schaefer et al. 2009), suggesting that this period of the late Holocene was relatively dry as well as cold.

\section{CONCLUSIONS}

New Zealand is by nature a mild, moist land of forests. Even during the height of Pleistocene glaciations much of the country remained vegetated and secondary calcite deposition continued in many caves. Thus speleothems are distributed through much of the time range covered by U-series dating, the troughs in the record of uranium-series ages probably being partly due to incomplete sampling rather than simply to widespread cessation of growth. Research agendas with sampling strategies focussing on the last glacial cycle and the high density of dating of some younger specimens contributes to the high frequency of dates at the younger end of the spectrum of ages presented in Fig. 3, but warm and wet conditions that favour speleothem growth in the Holocene compared to cold dry conditions in the LGM are also implicated in the changing form of the relative probability curve.

Because the growth spans of individual samples collected is often limited to a few tens of thousands of years, the construction of long records relies on the splicing together of overlapping series. This has been achieved by standardisation through adjustment of means. However, the resulting composite series 


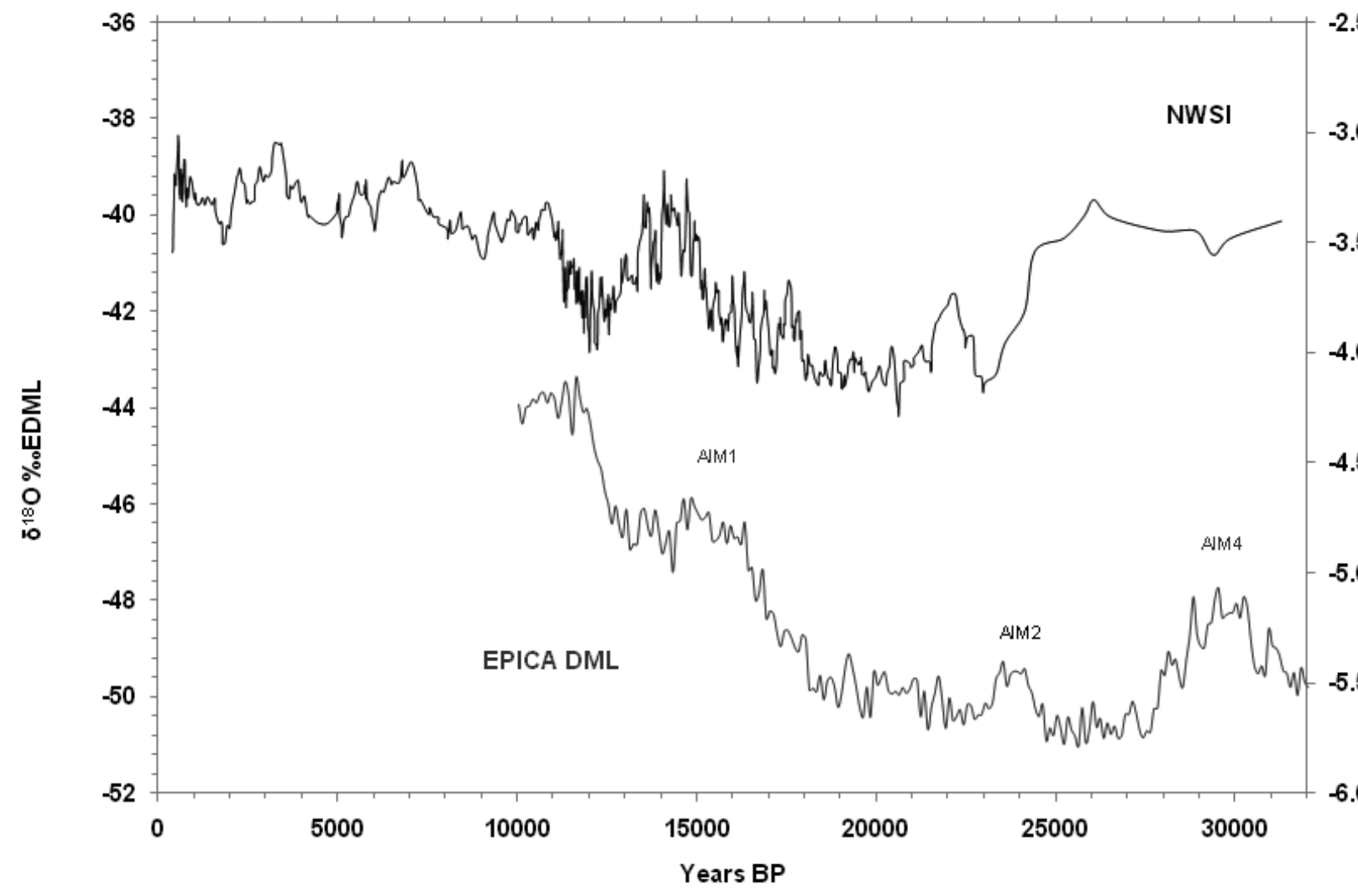

Fig. 9 Speleothem $\delta^{18} \mathrm{O}$ record from NWSI compared to Antarctic ice-core $\delta^{18} \mathrm{O}$ record from EPICA Dronning Maud Land (DML) [data downloaded from EPICA Community Members 2006.] AIM signifies Antarctic Isotope Maximum.

varies in reliability along its length, being most representative where sample depth is greatest and least dependable when the record relies on just one speleothem, because localised and random effects may then gain greater prominence.

The superimposed speleothem records used in the construction of composite series conform in general trend but, as detailed previously (Williams et al. 2005), often do not match in detail. This gives rise to a wide scatter of points around the general trend; this being an artefact of the method rather than a reflection of real climatic variability. Hence studies of high frequency climatic variability using proxy speleothem data should use individual rather than compound records. Composite records have their greatest value in identifying general trends and low frequency cycles, especially when they are constructed for sites within the boundaries of climatic regions.

The up-dated composite stable isotope records confirm the general conclusions reached by Williams et al. (2004, 2005), but add considerable extra detail. In particular, the NWSI record provides better definition of the LGM and Glacial-Interglacial transition. Termination 1 as revealed by $\delta^{18} \mathrm{O}$ records is a transitional rather than sharp boundary, but is more precisely defined in the $\delta^{13} \mathrm{C}$ record, and appears to have occurred at about the same time (18.1 ka) in New Zealand and Antarctica. However, other palaeoclimatic events between 30 and $10 \mathrm{ka}$ in the NWSI record distinctly lag their counterparts in Antarctica (EDML), usually by several hundred to a thousand years. This suggests that palaeoclimatic changes in New Zealand were driven by Antarctic influences, presumably transmitted by the circumpolar ocean circulation and strong westerly winds.

Less can be said about climatic leads or lags through the Holocene, because although the New Zealand records display marked peaks and troughs, the EPICA $\delta \mathrm{D}$ record after $8 \mathrm{ka}$ is essentially horizontal with little variation. However, the early Holocene optimum in EPICA is mirrored, though less strongly, in both the NWSI and CWNI $\delta^{18} \mathrm{O}$ series.

The $\delta$-values recorded in the speleothems discussed here have been transmitted by rain (moderated by soil and epikarst processes) brought from the Tasman Sea region of the SW Pacific. The immediate forcing factors for the observed palaeoclimatic variations are therefore most likely related mainly to changes in ocean source waters of precipitation, transmitted by westerly winds.

The northern boundary of the westerly wind circulation around the Southern Hemisphere varies between $46^{\circ}-48^{\circ} \mathrm{S}$ and lies just south of New Zealand. The boundary between subantarctic oceanic influences from the south and subtropical oceanic influences from the north is marked by the Subtropical Front, a zone centred about $45^{\circ} \mathrm{S}$ off western South Island in the southern Tasman Sea, but laying a few degrees further north off the east coast (Fig. 2). In the LGM this oceanic front will have migrated further north, driven by the increased strength of the westerly circulation (Shulmeister et al. 2004). But even in the Holocene the interface between subtropical and subantarctic influences would have 
remained dynamic. Thus the diverging $\delta^{18} \mathrm{O}$ curves illustrated in Fig. 7 are most likely a reflection of the waning of subtropical influences off the west coast of the North Island from $10-3 \mathrm{ka}$ as the westerly wind strength picked up from a minimum around $11 \mathrm{ka}$ to a secondary maximum in the late Holocene. The oscillating but near horizontal $\delta^{18} \mathrm{O}$ curve in the NWSI record over this interval suggests that the influence of subantarctic source waters of precipitation and the cool Westland Current (Fig. 2) off the western South Island were maintained with only minor perturbations.

\section{ACKNOWLEDGEMENTS}

We thank the NZ Foundation for Research, Science and Technology for funding support under contract UOAX0213 and previous contracts for P. Williams and H. Neil, and the Australian Research Council for supporting J-X. Zhao. The age model for GG5 was constructed by Sharleen Harper. We also wish to thank two anonymous referees whose constructive comments improved the paper.

\section{REFERENCES}

Alloway B.V., Lowe D.J., Barrell D.J.A., Newnham R.M., Almond P.C., Augustinus P.C., Bertler N.A.N., Carter L., Litchfield N.J., McGlone M. S., Shulmeister J., Vandergoes M.J., Williams P.W. \& NZ-INTIMATE members, 2007 - Towards a climate event stratigraphy for New Zealand over the past 30000 years (NZINTIMATE project). Journal of Quaternary Science, 22(1): 9-35.

Ayliffe L.K., Marianelli P.C. \& Moriarty K., 1998 - 500 ka precipitation record from southeastern Australia: evidence for interglacial relative aridity. Geology, 26: 147-50.

Baker A., Smart P.L. \& Ford D.C., 1993 - Northwest European paleoclimate as indicated by growth frequency variations of secondary calcite deposits. Paleogeography, Paleoclimatology, Paleoecology, 100: 291-301.

Barrows T.T., Lehman S.J., Fifield L.K. \& De Deckker P., 2007 - Absence of cooling in New Zealand and the adjacent ocean during the Younger Dryas chronozone. Science, 318: 86-88.

Bowen G.J. \& Wilkinson B., 2002 - Spatial distribution of $\delta^{18} \mathrm{O}$ in meteoric precipitation. Geology, 30(4): 315318.

Crawford S.J., 1994 - Hydrology and geomorphology of the Paparoa Karst, north Westland, New Zealand. Auckland Univ. Unpublished PhD thesis, New Zealand, $240 \mathrm{p}$.

Crossley P. (compiler), 2001 - The New Zealand Cave Atlas - North Island Supplement, NZ Speleological Society.

Crossley P., Hurst B. \& West R. (compilers), 1988 - The New Zealand Cave Atlas. Department of Geography, University of Auckland, for NZ Speleological Society.

Dansgaard W.F. 1964 - Stable isotopes in precipitation. Tellus, 16: 436-449.

EPICA Community Members 2006 - One-to-one coupling of glacial climate variability in Greenland and Antarctica. Nature, 444: 195-198.
Fink D., Williams P.W., Augustinus P. \& Shulmeister J., 2006 - Glacial chronologies across southern hemisphere latitudes during the past $30 \mathrm{ka}$ and correlations to Antarctic ice cores. In: Burge P.I., Shulmeister J. \& Turney C. (Eds), Australasian INTIMATE meeting, Human Sciences Building, University of Auckland, 10-11 February 2006: 14-16.

Ford D.C \& Williams P.W. 2007 - Karst hydrogeology and geomorphology. Wiley, Chichester, $562 \mathrm{p}$.

Gordon D., Smart P.L., Ford D.C., Andrews J.N., Atkinson T.C., Rowe P.J. \& Christopher N.J. 1989 Dating of late Pleistocene interglacial and interstadial periods in the United Kingdom from speleothem growth frequency. Quaternary Research, 31: 14-26.

Hellstrom J., McCulloch M. \& Stone J., 1998 - A detailed 31,000-year record of climate and vegetation change from the isotope geochemistry of two New Zealand speleothems. Quaternary Research, 50:167-178.

Hercman H., 2000 - Reconstruction of paleoclimatic changes in central Europe between 10 and 200 thousand years BP, based on analysis of growth frequency of speleothems. Studia Quaternaria, 17: 35-70.

Jouzel J., Masson-Delmotte V. , Cattani O., Dreyfus G., Falourd S., Hoffmann G., Minster B., Nouet J., Barnola J.M., Chappellaz J., Fischer H., Gallet J.C., Johnsen S., Leuenberger M., Loulergue L., Luethi D., Oerter H., Parrenin F., Raisbeck G., Raynaud D., Schilt A., Schwander J., Selmo E., Souchez R., Spahni R., Stauffer B., Steffensen J.P., Stenni B., Stocker T.F., Tison J.L., Werner M. \& Wolff E.W., 2007 - Orbital and Millennial Antarctic Climate Variability over the Past 800,000 Years. Science, 317 (5839): 793-797.

Kohn M.J. \& Welker J.M. 2005 - On the temperature correlation of $\delta^{18} \mathrm{O}$ in modern precipitation. Earth and Planetary Sciences Letters, 231: 87-96.

Lauritzen S-E., 1993 - Natural environmental change in karst: The Quaternary record. Catena Supplement, 25: 21-40.

Lorrey A.M., Williams P.W., Salinger J., Martin T.J. \& Fowler A.M., 2008 - Speleothem stable isotope records interpreted within a multi-proxy framework and implications for New Zealand palaeoclimate reconstruction. Quaternary International, 187: 52-75.

Ludwig K.R., 2008 - User's Manual for Isoplot 3.6: A Geochronological Toolkit for Microsoft Excel. Berkeley Geochronology Center Special Publication No. 4, 77 p.

Neil H. L., Carter L. \& Morris M., 2004 - Thermal isolation of Campbell Plateau, New Zealand, by the Antarctic Circumpolar Current over the past 130 kyr. Paleoceanography, 19: PA4008, doi: 10.1029/2003PA000975.

Richards D.A. \& Dorale J.A., 2003 - Uranium-series chronology and environmental applications of speleothems. Reviews in Mineralogy and Geochemistry, 52(1): 407-460.

Schaefer J.M., Denton G.H., Kaplan M., Putnam A., Finkel R.C., Barrell D.J.A., Andersen B.G., Schwartz R., Mackintosh A., Chinn T., Schlüchter C., 2009 High-Frequency Holocene Glacier Fluctuations in New Zealand Differ from the Northern Signature. Science, 324(5927): 622-625. 
Shulmeister J., Goodwin I., Renwick J., Harle K., Armand L., McGlone M.S., Cook E., Dodson J., Hesse P.P., Mayewski P. \& Curran M., 2004 - The Southern Hemisphere Westerlies in the Australasian sector over the last glacial cycle: a synthesis. Quaternary International, 118-119: 23-53.

Shulmeister J., Fink D. \& Augustinus P.C. 2005 - A cosmogenic nuclide chronology of the last glacial transition in North-West Nelson, New Zealand - new insights in Southern Hemisphere climate forcing during the last deglaciation. Earth and Planetary Science Letters, 233: 455-466.

Shulmeister J. \& McGlone M., 2008 - The Last Glaciation. In: Graham I. J., (Ed.) A Continent on the Move: New Zealand geosciences into the $21^{\text {st }}$ Century. Geological Society of New Zealand Miscellaneous Publication, 124: 268-9. (ISBN 9781-877480-00-3).

Smith N. (editor), 2004 - The New Zealand Cave Atlas. Vol. 2 South Island. Occasional Publication 12, NZ Speleological Society.

Sutherland R., Kim K., Zondervan A. \& McSaveney M., 2007 - Orbital forcing of mid-latitude Southern Hemisphere glaciations since $100 \mathrm{ka}$ inferred from cosmogenic nuclide ages of moraine boulders from the Cascade Plateau, southwest New Zealand. Geological Society of America Bulletin, 119 (3/4): 443-451.

Weaver P.P.E., Carter L. \& Neil H.L. 1998 - Response of surface water masses and circulation to late Quaternary climate change east of New Zealand. Paleoceanography, 13(1): 70-83.

Whittaker T.E., 2008 - High-resolution speleothem-based palaeoclimate records from New Zealand reveal robust teleconnection to North Atlantic during MIS 1-4. Unpublished $\mathrm{PhD}$ thesis, University of Waikato, New Zealand, $346 \mathrm{p}$.
Williams P.W., 1982 - Speleothem dates, Quaternary terraces and uplift rates in New Zealand. Nature, 298: 257-60.

Williams, P.W., 1992 - Karst in New Zealand. In: Soons, J. and Selby, M.J. (Eds), Landforms of New Zealand (second edition), Longman Paul, Auckland: 187-209.

Williams P.W., 1996 - A 230 ka record of glacial and interglacial events from Aurora Cave, Fiordland, New Zealand. New Zealand Journal of Geology and Geophysics, 39: 225-41.

Williams P.W. 2004a - The evolution of the mountains of New Zealand. In: Owens P.N. \& Slaymaker O. (Eds), Mountain Geomorphology, Arnold, London: 89-106.

Williams P.W., 2004b - Polygonal karst and palaeokarst of the King Country, North Island, New Zealand. Zeitschrift für Geomorphologie, Suppl., 136: 45-67.

Williams P.W., 2004c - Karst evolution on the West Coast of South Island, New Zealand, Australasian Cave and Karst Management Association Journal, 57: 4-11.

Williams P.W., King D.N.T., Zhao J.-X. \& Collerson K.D., 2004 - Speleothem master chronologies: combined Holocene $\delta^{18} \mathrm{O}$ and $\delta^{13} \mathrm{C}$ records from the North Island of New Zealand and their palaeo-environmental interpretation. The Holocene, 14(2): 194-208.

Williams P.W., King D.N.T., Zhao J.-X. \& Collerson K.D., 2005 - Late Pleistocene to Holocene composite speleothem chronologies from South Island, New Zealand - did a global Younger Dryas really exist? Earth and Planetary Science Letters, 230(3-4): 301-317.

Yuan D., Cheng H. \& Edwards R.L., 2004 - Timing, duration transitions of the last interglacial Asian monsoon. Science, 304: 575-8. 


\section{APPENDIX}

The data presented in Figs A1, A2 and A3 are new records included in the composite CWNI series shown in Figs 4, 7 and 8. Both Ruakuri A and Ruakuri B were judged to be in isotopic equilibrium because they conform with the general trend of the other speleothem series included in Fig. 4 and, in addition, Ruakuri C collected nearby had previously been shown to be in equilibrium (Williams et al. 2004). Gardners Gut 1 (GG1) and GG2 were also shown to be in isotopic equilibrium (Williams et al. 2004) and GG5 is also, as shown below by Hendy tests.
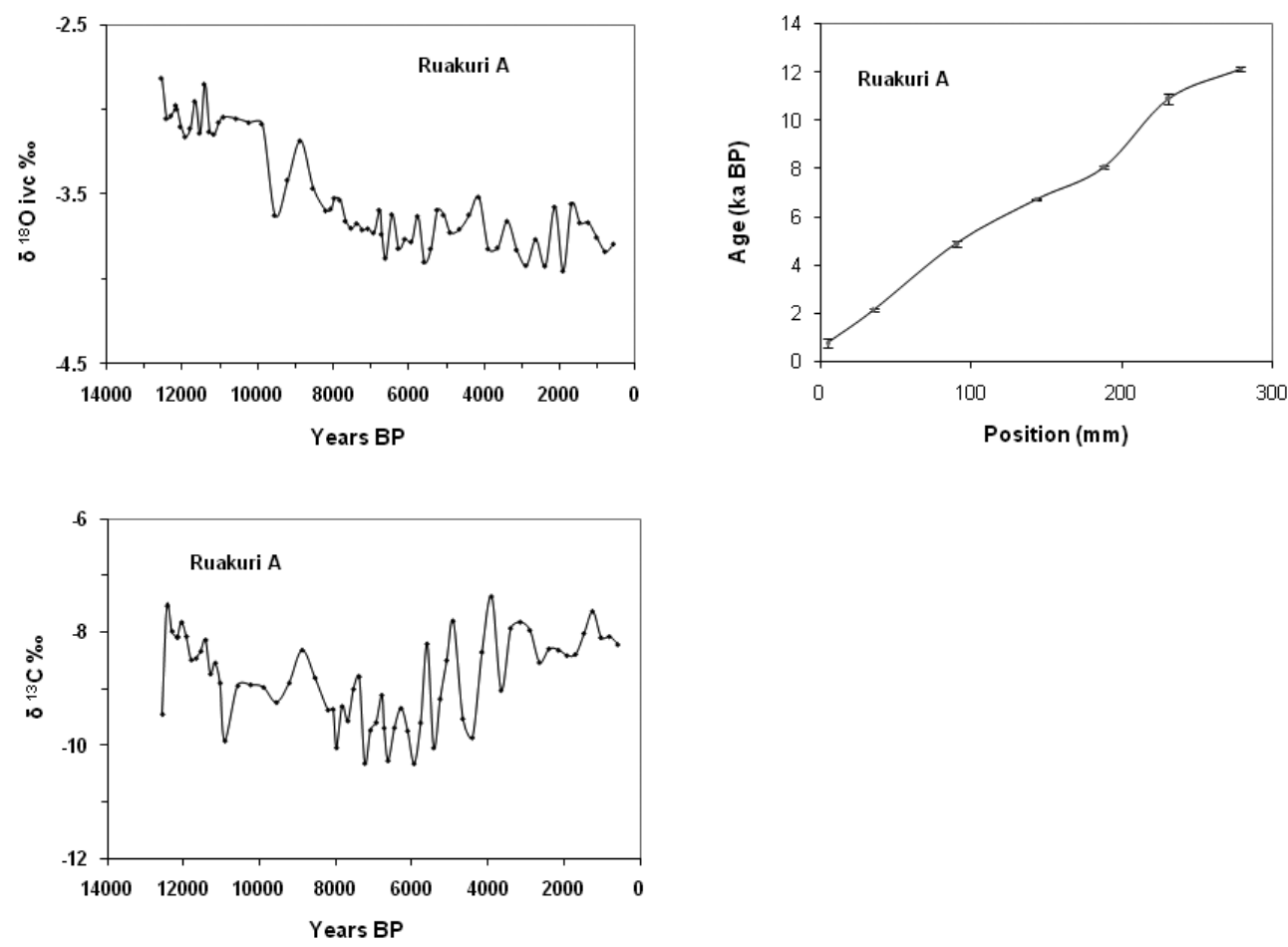

Fig. A1 .Ruakuri A showing trends for $\delta^{18} \mathrm{O}, \delta^{13} \mathrm{C}$ and the age model applied. Position errors for ages are $\pm 4 \mathrm{~mm}$. The age errors $(2 \sigma)$ are shown on the figure.
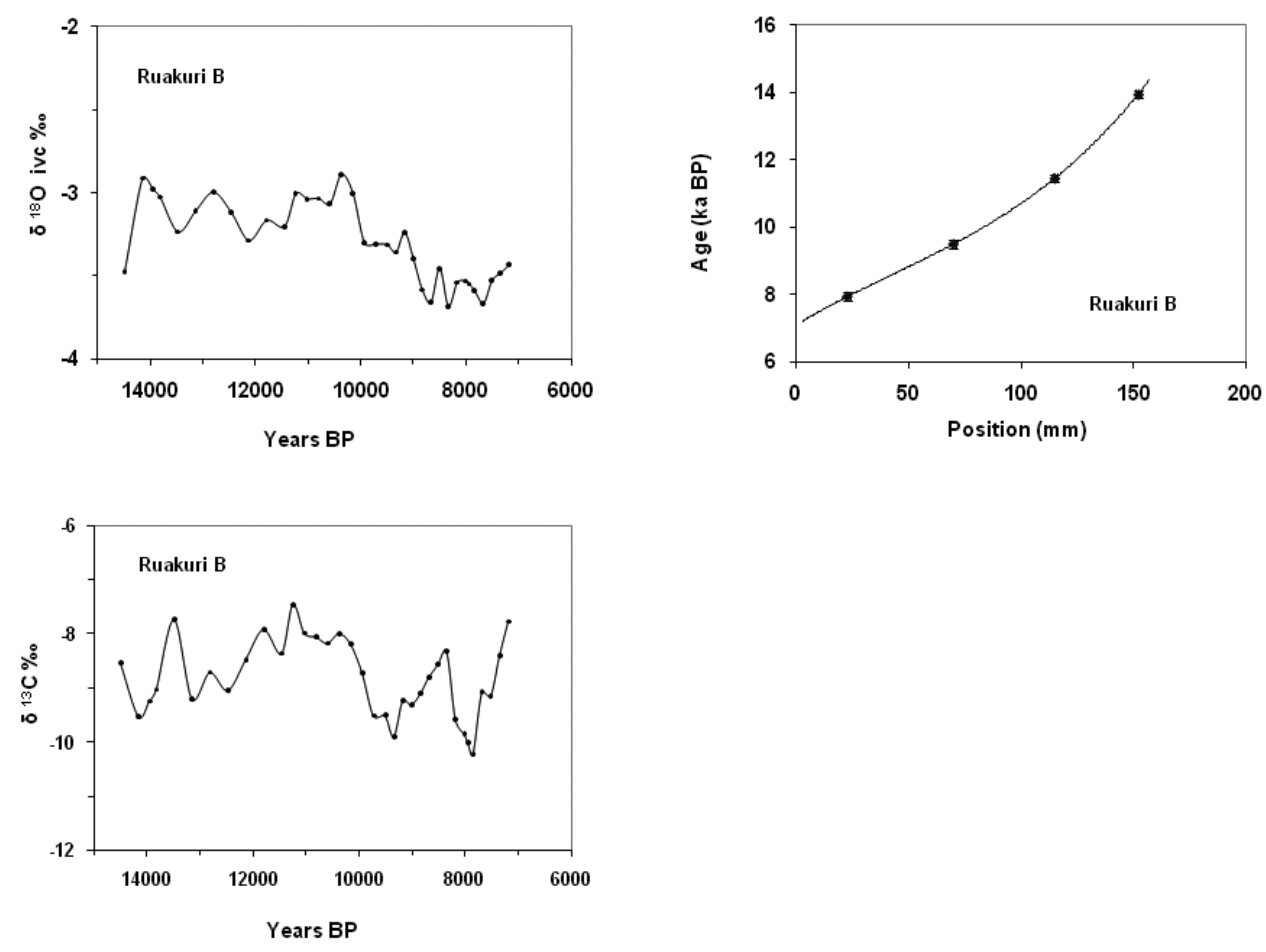

Fig. A2 .Ruakuri B showing trends for $\delta^{18} \mathrm{O}, \delta^{13} \mathrm{C}$ and the age model applied. Position errors for ages are $\pm 4 \mathrm{~mm}$. The age errors are shown on the figure and are often within the age symbol. 

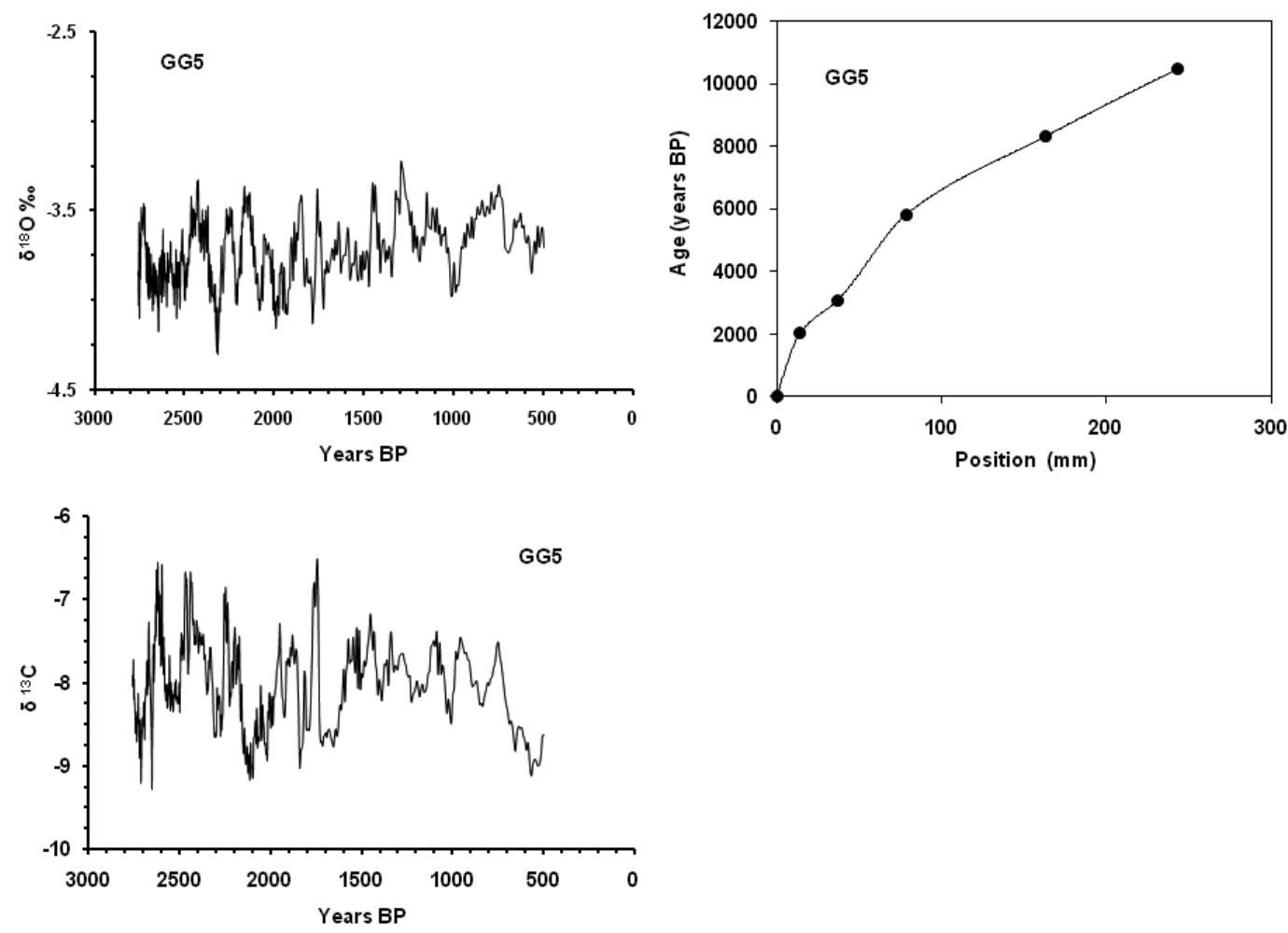

Fig. A3. Gardners Gut 5 (GG5) showing trends for $\delta^{18} \mathrm{O}, \delta^{13} \mathrm{C}$ and the age model applied. Position errors for ages are $\pm 4 \mathrm{~mm}$. The age errors are shown on the figure and are within the age symbol.
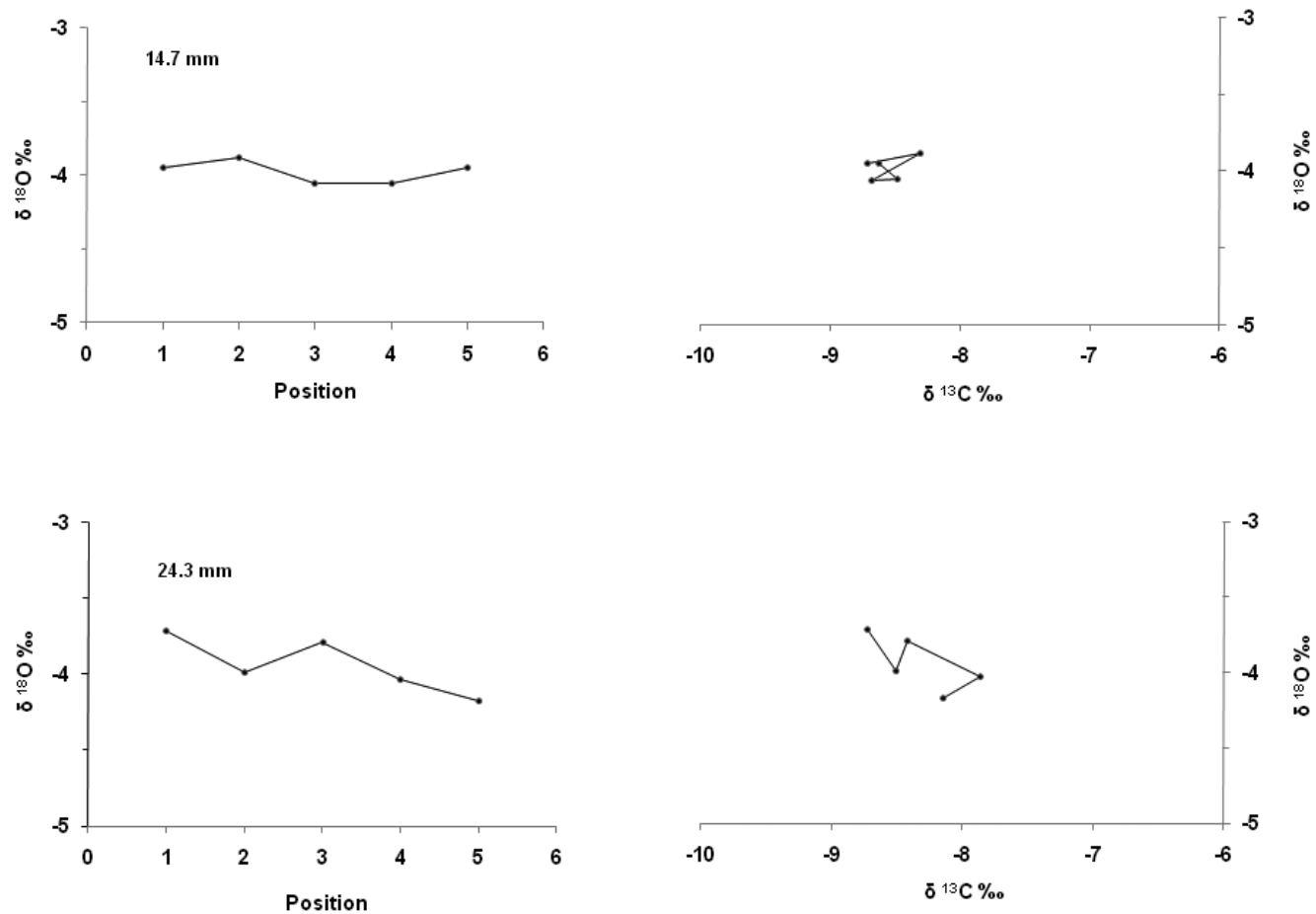

Fig. A4. Hendy tests on Gardners Gut 5 (GG5) stalagmite at $14.7 \mathrm{~mm}$ and $24.3 \mathrm{~mm}$ distance from the growing tip. Position refers to increasing distance along a growth line from the growth axis. Both cases are in isotopic equilibrium. 